\author{
Vol.7, Issue.2, December, 2019 \\ P-ISSN 2302-3783 \\ This work is licensed under a Creative Commons Attribution 4.o International License (cc-by)
}

\title{
Aspek Hukum Import Sampah Plastik
}

\author{
Solikah Ana Estikomah \\ Universitas Darussalam Gontor, Ponorogo-Indonesia. \\ Email Coresponden: Solikahana23@yahoo.com
}

\begin{abstract}
Indeveloped countriesbannedtoxic waste began to be recorded afterproved disastrous. In addition there isa gap for the cost of treating waste plastic in the developed countries anddeveloping countries. The high cost ofwastewater treatmentin plastic developed countries in part due to the high cost of compliance and strict law. In contrast, the low cost sewage treatment plastic in developing countriesdue to the lack of law enforcement. On the other hand, as a result of the construction waste requires complextechnology for processing and finaldisposal of hazardous materials is increasingly narrows with increasingawareness of the importance ofenvironmental protection. Waste-producing countries plastic and then look for the easiestand cheapest way to dispose of waste. Poor countries thatare developing targeted for regulation lingkungannnyastill weak. The existence of import export plastic waste between advanced and developing countries may be said to have lastedlong enough for the re-emergence of international public awareness of thedangers of pollution is industrial waste. The analysis research was conducted in a juridicalnormative manner based on literature study
\end{abstract}

Keywords: Waste, law, plastic, import

\begin{abstract}
Abstrak
Di negara-negara maju sampah beracun mulai dilarang untuk disimpan setelah terbukti menimbulkan bencana. Selain itu terdapat kesenjangan biaya untuk mengolah limbah sampah di negara-negara maju dan negara-negara berkembang. Tingginya biaya pengolahan limbah sampah di negara-negara maju sebagian disebabkan oleh tingginya biaya pentaatan dan hukum yang tegas. Sebaliknya, rendahnya biaya pengolahan limbah plastic di negara-negara berkembang disebabkan oleh lemahnya penegakan hukum. Di sisi lain, limbah sebagai dampak dari pembangunan memerlukan teknologi yang rumit untuk pengolahannya dan tempat pembuangan akhir bahan berbahaya beracun ini semakin menyempit seiring dengan meningkatnya kesadaran akan pentingnya perlindungan terhadap lingkungan. Negara-negara penghasil limbah plastic lantas mencari jalan termudah dan termurah untuk membuang limbahnya. Negara-negara miskin yang sedang berkembang yang menjadi sasaran karena peraturan lingkungannnya masih lemah. Keberadaan import sampah. Pada penelitian Analisis dilakukan secara yuridis-normatif berdasarkan studi pustaka.
\end{abstract}

Kata Kunci: Sampah, Hukum, Plastik, Import.

\section{Pendahuluan}

Menjelang pembukaan Konvensi Basel II yang membicarakan masalah ekspor sampah B3 beberapa-waktu yang lalu, kelompok Greenpeace menggelar aksi protes terhadap negara-negara Industri yang menentang pelarangan total ekspor sampah bahan berbahaya dan beracun (B3). Aksi yang melilbatkan tidak kurang 6o orang anggota kelompok pecinta lingkungan tersebut dilakukan 
dengan cara membuang satu ton sampah impor di depan markas besar PBB di Jenewa. Indonesia merupakan salah satu dari seratus empat puluh enam negara berkembang peratifikasi Konvensi Basel 1989 yang mengatur perpindahan samapah berbahan bahan berbahaya dan beracun yang selanjutnya disebut limbah B-3, namun Indonesia masih menjadi sasaran pembuangan limbah B-3 secara ilegal. (I Gusti Ayu Ketut Rachmi Handayani, Edi As'Adi, Guntur Hamzah, Tommy Leonard and Gunarto Gunarto, 2017)

Dengan adanya desentralisasi, sebagian besar urusan pemerintah saat ini telah dialihkan dari pemerintah pusat kepada pemerintah daerah. Hal ini mendorong banyak eksportir melirik kabupaten terutama daerah terpencil untuk menerima limbah plastic dengan iming-iming kompensasi yang besar untuk meningkatkan Pendapatan Asli Daerah (PAD). Eksportir negara maju membuang limbah plastik B-3 ke negara berkembang termasuk ke Indonesia dengan memberi imbalan yang menggiurkan. Namun, nilai itu lebih murah dibanding mengolah di negaranya karena harus memenuhi standar lingkungan yang tinggi. (Agus Surachman, I Gusti Ayu Ketut Rachmi Handayani and Yudho Taruno, 2017).

Tingginya intensitas kegiatan ekspor impor limbah yang mengandung plastic ke negara berkembang disebabkan oleh berbagai faktor. Pertama, kurangnya pengetahuan para pengambil keputusan tentang limbah plastic . Kedua, kurangnya sarana dan prasarana untuk mengetahui dan menganalisis limbah plastik. Ketiga, besarnnya biaya pengolahan limbah tersebut dan ketatnya peraturan pengelolaan lingkungan di negara-negara maju. Dan keempat, banyaknya tipu muslihat para eksportir. Negara-negara penghasil limbah plastik lantas mencari jalan termudah dan termurah untuk membuang limbahnya. Negara-negara miskin yang sedang berkembang yang menjadi sasaran karena peraturan lingkungannnya masih lemah. Keberadaan ekspor impor limbah plastik antara negara maju dengan negara berkembang boleh dikatakan sudah berlangsung cukup lama sampai munculnya kembali kesadaran masyarakat internasional terhadap bahaya dari pencemaran limbah industri tersebut. (Abdul Kadir Jaelani, I Gusti Ayu Ketut Rachmi Handayani, Isharyanto, 2019).

Untuk mengatasi akibat yang ditimbulkan oleh import plastik ini, maka perlu peraturan hukum yang jelas sebagai antisipasi untuk menghadapi dampak yang buruk terhadap lingkungan. Dalam mewujudkan tekad untuk menanggulangi masalah-masalah lingkungan, negara-negara telah mengikatkan diri pada perangkat hukum lingkungan internasional, baik yang berlaku secara global maupun yang bersifat regional. Kemudian negara-negara juga menindaklanjuti dengan peraturan hukum nasional untuk kepentingan perlindungan terhadap lingkungannya.Mengingat masalah tidak saja berskala nasional, tetapi juga internasional dan menyangkut berbagai aspek kehidupam manusia seperti teknologi, perdagangan, kesehatan, kebijaksanaan pemerinyah dan hukum, maka diperlukan kerjasama diantara negara-negara untuk mengatasinya. 


\section{Metode Penelitian}

Penelitian ini menggunakan metode penelitian yuridis-normatif dengan metode pendekatan konseptual dan pendekatan perundang-undangan. Data yang digunakan adalah data sekunder yang diperoleh melalui studi pustaka. Data yang terkumpul kemudian dianalasis dan disajikan secara deskriptif analitif. (Abdul Kadir Jaelani, I Gusti Ayu Ketut Rachmi Handayani, Lego Karjoko, 2019)

\section{Hasil dan Pembahasan}

\section{Dampak Sampah Plastik Import}

Sampah plastik impor yang masuk ke Indonesia jelas mempunyai dampak terhadap kehidupan masyarakat, baik terhadap kehidupan ekonomi maupun terhadap lingkungan hidup. Namun demikian harus dibedakan antara dampak yang ditimbulkan oleh sampah plastik impor yang mengandung B3 dan sampah plastik impor yang tidak mengandung B3. Sampah plastik impor yang mengandung B3 mempunyai tingkat bahaya lebih tinggi daripada sampah plastik impor yang tidak mengandung $\mathrm{B}_{3}$. Sampah atau limbah yang mengandung $\mathrm{B}_{3}$ memiliki karakteristik mudah meledak, mudah terbakar, bersifat reaktif, beracun, bersifat korosif, dan bisa menyebabkan infeksi dan bisa menyebabkan infeksi. Dampak sampah plastik impor terhadap kehidupan ekonomi masyarakat terutama berkaitan dengan kerugian finansiai yang dialami oleh Indonesia, yaitu biaya pengolahan sampah plastik Impor tersebut, harga sewa lokasi kontainer dl pelabuhan dan kemgian yang dialami para pemulung. (Lego Karjoko, Yulfitri Nurjanah, 2019)

Kasus sampah plastik impor yang terjadi dalam masyarakat kita terutama disebabkan oleh kelemahan sistem peraturan perundang-undangan, khususnya peraturan tentang ekspor impor sampah dan limbah bahan berbahaya dan beracun. Sebagian besar sampah plastik impor yang masuk ke Indonesia datang sebelum Indonesia memiliki peraturan perundang-undangan yang melarang impor sampah dan adaya peraturan tentang limbah bahan berbahaya dan beracun. Sebenarnya pemerintah sudah mendeteksi adanya impor sampah atau limbah bahan berbahaya dan beracun pada tahun 1989, ketika itu Menteri KLH mengirim surat imbauan kepada para gubernur agar menolak setiap Impor sampah yang mengandung bahan berbahaya dan beracun yang niasuk ke pelabuhan-pelabuhan di daerahnya. Namun masalah Itu tidak ditindaklanjuti dengan pembuatan peraturan perundang-undangan hasil Konvensi Basel pada waktu itu. Adanya kekosongan aturan hukum tersebut dimanfaatkan secara jeli oleh para pengusaha dan Industriawan dari Belanda, Jerman, Amerika Serikat, Jepang, Singapura, dan Hongkong untuk mengekspor sampah atau limbah yang ada di negara mereka ke Indonesia. (Suwari Akhmaddhian, Hartiwiningsih \& I Gusti Ayu Ketut Rachmi Handayani, 2017)

Para pengusaha dan kalangan industriawan Indonesia yang bergerak dalam industri daur ulang sampah membutuhkan sampah dari negara-negara Industri tersebut sebagal bahan baku untuk Industri daur ulang yang mereka kelola. Dengan adanya perrnintaan dan penawaran tersebut, maka kemudian lahir berbagai transaksi dagang sampah plastik dan limbah bahan berbahaya dan beracun. Industri daur ulang sampah plastik sebenarnya tidak ada masalah 
sepanjang bahan bakunya tidak mengandung $\mathrm{B}_{3}$, walaupun sampah plastik Itu berasal dari hasil impor. Adalah sangat mengherankan, mengapa para pengusaha Indonesia mau menglmpor'sampah plastik mengandung B3 yang jelas-jelas tidak bisa didaur ulang. Motif negara.-negara industri untuk menglmpor sampah plastik atau limbah lainnya, terutama sampah atau limbah yang mengandung B3 adalah karena alasan praktis dan ekonomis. Untuk mendaur ulang' sampah dan atau membuang sampah yang rnengandung B3 di negara-negara industri persyaratannya jelas sangat komprehensif dan blayanya juga sangat besar. Oleh karena itu lebih praktis dan ekonomis jika diekspor ke negara lain. Dengan kata lain, kebijakan ekspor tersebut lebih menguntungkan daripada mengolah sendiri. Bagi pengusaha dalam negeri impor sampah plastik yang tidak mengandung $\mathrm{B}_{3}$ dilatarbelakangi oleh motif bisnis untuk men'dapatkan keuntungan,yang sebesarbesarnya, karena harga plastik impor itu lebih murah daripada harga plastik yang dikumpulkan para pemulung. (Abdulatti Abdullah Algonin, Ashabani Mohamed Shleag, Gusti Ayu Ketut Rachmi Handayani and Prabang Setyono, 2014)

Namun tindakan mengimpor sampah plastik yang telah terkontaminasi B3 atau mengimpor limbah B3 Itu sendiri sulit melacak motif yang melatarbelakanginya. Probabilitas yang paling mungkin adalah persekongkolan jahat dengan Imbalan uang. Dengan kasus sampah plastik impor ini terlihat bahwa hukum mempunyai peranan penting dalam kehidupan masyarakat. Hukum mengatur bagaimana kehidupan masyarakat seharusnya dilaksanakan. Tujuannya ' adalah untuk menciptakan kedamaian dalam pergaulan hidup bersama. Kedamaian akan tercipta apabila ada keter-tiban (keteraturan dalam interaksi sosial) dan adanya ketenteraman (kebebasan untuk mengekpresikan diri). Tanpa hukum tidak mungkin tercipta ketertiban dan ketenteraman dalam kehidupan masyarakat, termasuk ketertiban dan ketenteraman dalam ekspor impor sampah plastik dan bahan berbahaya dan beracun. (Rahayu Subekti, Adi Sulistiyono and I Gusti Ayu Ketut Rachmi Handayani, 2017)

\section{Kebijakan Pemerintah Mengenai Sampah Impor}

Pengolahan dan pembuangan limbah $\mathrm{B}_{3}$ yang berisiko minimum bagi manusia dan lingkungan hidup merupakan tantangan penting bagi pemerintah dan juga bagi industrl. Namun tidak semua negara dan industri mengambil kebijakan tersebut. Cara yang semakin banyak digunakan untuk mengatasi masalah ini adalah dengari mengangkut (mengimpor) limbah B3 ke negara lain.Cara ini adalah cara yang paling mudah dan ekonomis. karena jika mengolah sendiri biayanya cukup mahal.,Oleh karena Itu terjadi peningkatan permintaan investasi untuk pembuangan limbah. In donesia merupakan salah satu tujuan dari pembuangan limbah $B_{3}$ ini. Untuk mengantisipasi peningkatan permintaan untuk investasi pembuangan limbah B3 dari luar negerl tersebut, pada tahun 1989 Menteri Negara Kependudukan dan Lingkungan Hidup telah mengeluarkan surat yang berisi imbauan kepada seluruh gubernur di wilayah Indonesia untuk menolak tanah air Indonesia dijadikan tempat pembuangan limbah dari negara lain. Walaupun sudah ada imbauan, namun kenyataannya, kasus sampah plastik impor disinyalir sudah terjadi sejak akhir..1991. Indikasi terjadinya manipulasi 
kasus pemasukan sampah plastik impor yang mengandung limbah B3 berawal dari Informasi para pemulung (scavengers atau plastic garbage collector). (I Gusti Ayu Ketut Rachmi Handayani, I Ketut SEREGIG, Teguh Prasetyo and Ardi Gunardi, 2017).

Limbah B3 tersebut bercampur dengan limbah plastik untuk didaur uiang. Salah satu contoh adalah ditemukan drum-drum yang berluliskan Lechitine. Kebijakan pemerintah dalam menghadapi masalah sampah plastik impor inidapat dibedakan antara kebijakan pengaturan hukum (regulation policy) dan kebijakan penyelesaian kasus (case set tlement policy). Ada tiga macam kebijakan pengaturan hukum yang dilakukan pemerintah untuk meresppn kasus sampah plastik Impor, yaitu pelarangan impor sampah plastik melalui Surat Keputusan Menteri Perdagangan No. 349/ Kp/XI/1992, peratifikasian Konven $\wedge^{\wedge} \mathrm{i}$ Basel yang mengaturtentang Pengawasan dan Perpindahan Lintas Batas Limbah Berbahaya dan Pembuangannya, dan Pembuatan Peraturan Pemerintah No. 19 Tahun 1994 tentang Pengolahan Limbah Bahan Berbahaya dan Beracun.

Dasar pelarangan Impor sampah plastik menurut konsideran SK Menteri Perdangan No. 349/Kp/XI/1992 adalah dalam rangka pencegahan pencemaran terhadap lingkungan dan- kesehatan manusia yang diakibatkan oleh sampah plastik, khususnya yang berasal dari Impor. Tindakan pemerintah melarang impor sampah plastik secara total, termasuk jenis sampah plastik yang dapat didaur ulang (positive list), jelas memberikan keuntungan ganda bagi Indonesia. Pertama, berkurangnya penumpukan sampah karena sampah plastiklokal dibell oleh industrl daur ulang, sehingga mengurangi beban pemerintah untuk menyediakan lahan pembuangan sampah. Kedua, penyediaan lapangan kerja bagi para pemulung dapat dilestarikan. Sayang sekali Surat Keputusan Menteri Perdagangan yang melarang Impor sampah plastik tersebut. tidak disertai dengan sanksi hukum bila ketentuan tersebut dilanggar sehingga secara yuridis formal peraturan tersebut lemah. (Zaidah Nur Rosidah, Diana Zuhroh, Farhan \& Lego Karjoko, 2017)

Untuk melengkapi kedua aturan tersebut, pada tanggal 30 April 1994 pemerintah memberlakukan PP No 19 Tahun 1994 tentang Pengolahan Limbah Bahan Berbahaya dan Beracun. Meskipun PP ini lebih banyak mengatur pengolahan limbah berbahaya dan bahan beracun yang dihasilkan.dalam negeri, namun juga mengatur tentang pengawasan impor dan ekspor limbah B3. Ketentuan PP No. 19 Tahun 1994 Pasal 27 menyebutkan: (Lusia Savitri Diah Candrasari, Lego Karjoko, 2018)

1) Setiap orang atau badan usaha dilarang memasukkan limbah $\mathrm{B}_{3}$ dari luar negeri ke dalam Wilayah Negara Republik Indonesia.

2) Pengangkutan limbah $B_{3}$ dari luar negeri melalui Wilayah Negara Republik Indonesia, wajib dilakukan memberitahukan terlebih dahulu secara tertulis kepada Pemerintah Republik Indonesia.

3) Penglriman limbah $B_{3}$ ke luar negeri dapat dilakukan setelah mendapat persetujuan tertulis dari pemerintah negara penerima dan mendapat izin tertulis dari Pemerintah Republik In donesia. 
4) Ketentuah lebih lanjut mengenal tata cara penglriman limbah $\mathrm{B}_{3}$ ke luar negeri ditetapkan Menteri Perdagangan setelah mendapat pertimbangan Badan Pengendali Dampak Ling-kungan.

Pelanggaran terhadap ketentuan dalam PP ini dapat dikenakan sanksi administratif berupa peringatan dan pencabutan ijin usaha. Pengangkutan limbah B3 yang menggunakan sarana transportasi yang tidak memenuhl ketentuan pengangkutan diancam dengan sanksi yang terdapat dalam peraturan perundang-undangan dl bidang perhubungan. Ketentuan-ketentuan lain yang dikeluarkan pemerintah dalam menghadapi masalah sampah plastik impor adalah sebagal berikut: (Lego Karjoko, I Gusti Ayu Ketut Rachmi Handayani and Adi Sulistiyono, 2017)

a. Surat Menteri Muda Perdagangan No. S-107/M/XI1/ 1992 mengenai permintaan peninjauan kembali atas SK Menteri Perdagangan, Surat dikeluarkan tanggal 18 Desember 1992.

b. Surat Menteri Keuangan No. S-1571/ MK.oo/1992 tentang Pemberlan Ijin Pemasukan ke Daerah Pabean atas Party LImbah/Sampah Plastik yang dikapalkan dari negara asal sebelum atau pada tangal 25 November 1992. Surat dikeluarkan tanggal 30 Desember 1992. 4. Surat Direktorat Jenderal Pabean No. S-16/BC.3/1993 tentang Pelaksanaan SK Menteri' Keuangan. Surat dikeluarkan tanggal 5 Januari 1993.

c. Surat Dirjen Bea Cukai: RDG/Dirjen Bea Cukal/RDG No. 02/BC/1993 tentang Penghentlan Pelaksanaan SK Menteri Keuangan. Surat dikeluarkan tanggal 3 Pebruarl 1993.

d. Surat Keputusan Jaksa Agung: SKEP No. Kep-027/JA/2/1993 mengenal Pembentukan Tim Penanggulangan Impor Limbah. Surat dikeluarkan tanggal 12 Pebruaii 1993

e. Surat Dirjen Bea Cukai S-104/BC/1993 dan SE-o6/BC/1993 tentang: (a) Importir dapat mengurus PIUD sampal tanggal 15 April 1993; (b) Kontainer yang tidak diambil sampal tanggal 12 April 1993 akan dilelang; (c) Lelang dilakukan dengan syarat; tidak mencemari lingkungan dan slap membeli sampah plastik pemulung dengan perbandingan 1:3. Kedua surat tersebut dikeluarkan pada tanggal 15 Maret 1993 dan 16 Maret 1993.

f.Surat Wakil Sekretaris Kablnet No. 27/ WASESKAB/ 4/ 1993 berisi Petunjuk Presiden bahwa Limbah Impor agar dimusnahkan.

\section{Penutup}

Berdasarkan uraian di atas dan berdasarkan rumusan masalah maka kesimpulan yang bisa diperoleh adalah sampah plastik impor yang masuk ke Indonesia jelas mempunyai dampak terhadap kehidupan masyarakat, baik terhadap kehidupan ekonomi maupun terhadap lingkungan hidup. Namun demikian harus dibedakan antara dampak yang ditimbulkan oleh sampah plastik impor yang mengandung limbah $\mathrm{B}_{3}$ dan sampah plastik impor yang tidak mengandung limbah B3. Sampah plastik impor yang mengandung limbah B3 mempunyai tingkat bahaya lebih tinggi daripada sampah plastik impor yang tidak mengandung B3. Sampah atau Iimbah yang tergolong limbah B3 memiliki 
kharakteristik mudah meledak, mudah terbakar, bersifat reaktif, beracun, bersifat korosif, dan bisa menyebabkan infeksi dan bisa menyebabkan infeksi. Dampak sampah plastik impor terhadap kehidupan ekonomi masyarakat terutama berkaitan dengan kerugian finansiai yang dialami oleh Indonesia, yaitu biaya pengolahan sampah plastik Impor tersebut, harga sewa lokasi kontainer dl pelabuhan dan kemgian yang dialami para pemulung. Mengingat masalah import sampah yang tidak saja berskala nasional, tetapi juga internasional dan menyangkut berbagai aspek kehidupam manusia seperti teknologi, perdagangan, kesehatan, kebijaksanaan pemerintah dan hukum, maka diperlukan kerjasama diantara negara-negara untuk mengatasinya. Pada mulanya sampah lebih dianggap sebagai masalah negara-negara maju. Akan tetapi dalam perkembangannya, ketika sampah menjadi salah satu objek atau komoditi yang dapat diperjualbelikan, banyak negara maju menjadikan negara berkembang yang miskin sabagi sasaran tempat pembuangan sampah yang tergolong bebahaya baik secara sah (legal) dan tidak sah (illegal). Dengan demikian limbah import sampah tidak lagi dianggap sebagai masalah nasional dan regional, tetapi menjadi masalah global.

\section{References}

Abdul Kadir Jaelani, I Gusti Ayu Ketut Rachmi Handayani, Isharyanto, "Regulation of Regional Government on Halal Tourism Destinations in West Nusa Tenggara Province after Constitutional Court Decision Number 137/PUU-XIII/2015”, Proceeding Atlantis Press: Advances in Social Science, Education and Humanities Research, Volume 358, Tahun 2019.

Abdul Kadir Jaelani, I Gusti Ayu Ketut Rachmi Handayani, Lego Karjoko, "Executability of the Constitutional Court Decision Regarding Grace Period In The Formulation Of Legislation", International Journal of Advanced Science and Technology Vol. 28, No. 15, (2019).

Abdulatti Abdullah Algonin, Ashabani Mohamed Shleag, Gusti Ayu Ketut Rachmi Handayani and Prabang Setyono, "Variation of Environmental Awareness among the Student in Government High Schools in Solo City Indonesia", International Journal of Applied Engineering Research Volume 9, Number 21 (2014)

Agus Surachman, I Gusti Ayu Ketut Rachmi Handayani and Yudho Taruno, "Effect of Globalization on Establihment of Water Resource Law: A Practice in Indonesia", International Journal of Economic Research, Volume 14, Number 13 (2017).

I Gusti Ayu Ketut Rachmi Handayani, Adi Sulistiyono, Tommy Leonard, Ardi Gunardi and Fatma Ulfatun Najicha, "Environmental Management Strategy in Mining Activities in Forest area Accordance with the Based Justice in Indonesia", Journal of Legal, Ethical and Regulatory Issues, Volume 21, Issue 2, 2018.

I Gusti Ayu Ketut Rachmi Handayani, Edi As'Adi, Guntur Hamzah, Tommy Leonard and Gunarto Gunarto, "Relationship Between Energy Consumption in International Market and Indonesia Prices Regulation”, International Journal of Energy Economics and Policy, Vol.7, Issue 5 (2017).

I Gusti Ayu Ketut Rachmi Handayani, I Ketut Seregig, Teguh Prasetyo and Ardi Gunardi, "The Application Of Article 359 Of The Criminal Code In The Investigation Of The Death Of Post-Operative Patients", Journal of Advanced Research in Law and Economic Vol, 8, Isue 5 (2017). 
Lego Karjoko, I Gusti Ayu Ketut Rachmi Handayani and Adi Sulistiyono, "Setting of Plantation Land Area Limitation Based on Social Function Principles of Land Cultivation Rights to Realize Social Welfare-Promoting Plantation, Jurnal Dinamika Hukum, Volume 17 No 1 (2017)

Lego Karjoko, Yulfitri Nurjanah, "The Legality of Freehold Title and Legal Implications Against of Land Makers Officers (The Study of Freehold Title Issuance Number 1576/Nusukan Village, Banjarsari Sub-District, Surakarta City, Central Java)", International Journal of Scientific and Technology Research 8(10), 2019.

Lusia Savitri Diah Candrasari and Lego Karjoko, "Principle of Social Function of Land Cultivation Right in Agritourism Accommodation in Indonesia", International Journal of Multicultural and Multireligious Understanding, Vol. 5, No. 2, April 2018.

Rahayu Subekti, Adi Sulistiyono and I Gusti Ayu Ketut Rachmi Handayani, "Solidifying the just law protection for farmland to anticipate land conversion", International Journal of Economic Research, Volume 14, Number 13 (2017).

Suwari Akhmaddhian, Hartiwiningsih \& I Gusti Ayu Ketut Rachmi Handayani, "The Government Policy of Water Resources Conservation to Embodying Sustainable Development Goals: Study in Kuningan, Indonesia”, International Journal of Civil Engineering and Technology, Volume 8, Issue 12, (2017).

Zaidah Nur Rosidah, Diana Zuhroh, Farhan \& Lego Karjoko, "Justiceaspect Ofthe Settlement Dispute Insharia Business Through The Religious Court", South East Asia Journal of Contemporary Business, Economics and Law, Vol. 12, Issue 4 (2017) 